\title{
PRODUCTION OF ALTERNATIVE CULTURE
} MEDIUM BY USING DIFFERENT PLANT

\section{EXTRACTS, VEGETABLES AND FRUIT JUICES - A REVIEW}

\author{
Logeshwaran .V, Sabarinath .K, Sandhiya.S, Ishwarya .R, Kousalya.N , Arun.P \\ Department of Biotechnology, \\ Dr. N.G.P. Arts and Science College,
}

\begin{abstract}
The production of the alternative culture media using the plant extracts. Its gives the nutrients to the microbial growth. Different types of the fruit juices and vegetables and other plant extract are used as the alternative microbial growth and maintenance media. In this production of alternative media beetroot, carrot, rye, tomato, soya bean, corn meal and natural fruit juices V8, V6 also used. It gives the positive results and give the good microbial growth.
\end{abstract}

Keywords: Culture media, Vegetable, Fruit juices, Plant extracts.

\section{INTRODUCTION}

The microbial growth needs a suitable environment conditions. In the laboratory purposes commercially developed mediums are used for the microbial growth. These medium contain different types of the nutrients, amino acids, vitamins and other chemical and biological substances and also these media contains carbon, nitrogen, phosphorus, sulfur, irons and metal ions. These culture media is used for the identification of microorganisms. It used as microbial growth media and maintenance of the pure culture.

Media is prepared by two different forms of liquid and solid. In the liquid medium used in test tube. Solid media used in petri plate. In the solid agar-agar is used for solidification it used as the solidify agent. It used for preparation of the solid and semi-solid media. Different types of the media is commercially available. In those media contains of different nutrients that's are animal (beef) extract, yeast extract, vegetable extract, natural fruit juices are used. Some of the alternative culture media preparation plant extract is used. It directly used as liquid medium or used solid from with agar-agar. In this review containing the information about the different plant extract or vegetables how enhance the microbial growth and using those vegetable to produce alternative media.

\section{DIFFERENT TYPES OF PLANT EXTRACTS USED AS MEDIUM}

Different types of the fruit juices and vegetables and other plant extract are used as the alternative microbial growth and maintenance media. In this beetroot, carrot, rye, tomato, soya bean, corn meal and natural fruit juices V8, V6 also used.

\section{USING BEETROOT AS A MEDIA}

Beta vulgaris root extract or (beet root juices) was prepared under sterile conditions. (1) first time used experimental medium for they mycobacterium spp. In this experiment they have positive results the bacterial growth observed after 3days, this medium also used to maintain bacteria for 24days same beetroot extract is used to enrich the media with agar-agar. In this process the bacterial growth is observed after 7days. We can use these extract as liquid or solid agar medium. It providing a suitable growth. So we use these media as alternative microbial culture media (L.S)

Ahmed -A.M(2) using beetroot juice as a growth and maintenance media for the pathogenic bacteria $\mathrm{s}$ are pseudomonas, aeruginosa, proteus vulgaris, staphylococcus aureus, Escherichia coli and klebsiella pneumoniae. This is used as alternative growth medium for nutrient agar and nutrient broth for the microbial growth in the laboratory

All the tested bacteria $\mathrm{s}$ are gives the active growth after the 24 hours. This beetroot extract used directly as liquid medium. It maintains the bacteria viable for the 7 days same bacteria observed in the solid media (enrich with agar agar). That bacteria maintained for 10 days. These results suggested that we can use the beetroot extract as the alternative growth media.

\section{USING DIFFERENT PLANT EXTRACTS USED AS MEDIA}

M.Mohasan (3) Using different plant extract as the different growth media evaluated against the mycelial growth of phytophthoracapsici and they compared with four different plant extract medium 


\section{International Journal of Engineering Applied Sciences and Technology, 2019 \\ Vol. 4, Issue 8, ISSN No. 2455-2143, Pages 371-373 \\ Published Online December 2019 in IJEAST (http://www.ijeast.com)}

- $\quad$ PARAP (corn meal agar used)

- Carrot agar medium

- Onion agar medium

- Rye agar medium

- V8 and v6 juice agar

All these media is prepared by same procedure plant extract or vegetable or seeds (in grams) are taken wash with tab water then blended the vegetables after that filter with muslin cloth. Likewise v8,v6 juices are taken then caco3 (2g) and Then agar ager was added to the all the filtered mixture and mix properly and autoclave was done at $121^{\circ} \mathrm{C}$ at $15 \mathrm{psi}$ after cooling the mediumlcc streptomycin was added and poured in Petri plates and allowed to solidify.

PDA is the best medium but same time these plant extracts are gives good mycelial growth. Onion and radish gives good pathogen development. v6 juice $64 \mathrm{~mm}$, v8juice agar $57 \mathrm{~mm}$, onion agar $55 \mathrm{~mm}$, PDA agar $54 \mathrm{~mm}$. these results show the plant extracts are giving very good microbial growth

\section{USING TOMATO AGAR AND SOYABEEN AGAR ALTERNATIVE FOR V8 JUICE}

V8 vegetablejuices used as a microbial growth media (4) but these juices is not available in the all the country and difficult to obtain. Using the tomato and soya bean agar is alternative media for the $\mathrm{v} 8$ juice and it give linear growth of the phytophthoraand Pythium sp.

\section{USING VEGETABLE AND FRUIT WASTE}

We can use kitchen waste as the alternative culture media because it containing nutritional values. The commercially developed mediums are high cost. using these vegetables and fruit wastes are easily available and produce low cost media and also it containing protein and starch they taken nine differentformulations of natural nutrient sourceof cauliflower, potato, fenugreek,orange peel and drumstick peel in these drumstick seed and peel medium supported growth of E.coli., Serratia sp., pseudomonas sp.

\section{USING VEGETABLE NUTRIENT SOURCE:}

The microbial culture media high cost so we can alternatively produce using cheap local raw food materials (potato, groundnut, cereals, cassava, yam, pigeon pea, maize, and beans) these vegetables are containing very good nutrients and used as liquid or solid media based on the selected microbes these vegetable media give good growth similar to the commercial medium. These media is cheap and performed well against the different bacteria and fungi. They tested with staphylococcus sp., e.coli., salmonella sp., klebsiella sp., and aspergillus sp.,

\section{USING PLANT PROTEIN SOURCE}

Legume seeds are containing a good protein source for nutritional values. So we can use legume seeds as an alternative nutrient medium for the microbial growth. Cowpea, green gram, black gram and soya meat (processed soya bean) were used. The test organisms used were E. coli,Bacillus sp., Klebsiella sp., Staphyllococcus sp. and Pseudomonas sp. Staphyllococcus sp. grows well but Klebsiellaspslowly grow.All the protein formulations tested. In compare to the nutrient agar media, the prepared protein formulations are worked well and it is good alternative culture media for bacteria.

\section{CONCLUSION}

Commercially developed microbial culture media is high cost. Alternative low cost media production we can use the natural pant source such as vegetables and fruits. These vegetables are rich in protein, amino acids other nutrients. It act as the similar to the commercial media and it stimulate the microbial growth.

\section{FURTHER INFORMATION}

V8 juice contains 8 vegetables that are French bean, celery, carrot, potato, lettuce, tomato, water leaf and sugar beet.

\section{ACKNOWLEDGEMENT}

The author express their gratitude towards the host Institution Dr.N.G.P. Arts and Science college, Management, Principal, Deans, Head of the department, guide and other all other staffs of Department of biotechnology for rendering all the facilities and support. Communication no: DrNGPASC 2019-20 BS018.

\section{REFERENCE}

[1] Al-Azzauy, A. A. M. (2002). The extraction of (RA) $\&$ (BA) plant stains and the use of them in the viability test of Echinococcus granulosus protoscolices, patent, registered by the central organization for standardization and quality control, IraqBaghdad, no. of patent 3031.

[2] Al-Azzauy, A. A. M. and Salman, A. M. H., 2011. The beetrootjuice as a bacterial growth and maintenance medium for manypathogenic bacteria, Iraqi J. of Market Res. and ConsumerProtection, Vol. 3, No. 5, pp. 147-161.

[3] Ahmed A Mohammed, Suhad Faisal Hatem AlMugdadi, BasmaTalib Al-Sudani, Jinan K. Kamel Beetroot juice as an alternative growth and maintenance medium for six isolates of 


\section{International Journal of Engineering Applied Sciences and Technology, 2019 \\ Vol. 4, Issue 8, ISSN No. 2455-2143, Pages 371-373 \\ Published Online December 2019 in IJEAST (http://www.ijeast.com)}

Mycobacterium spp.Ahmed A Mohammed et al /J. Pharm. Sci. \& Res. Vol. 10(8), 2018, 1881-1884

[4] G.R. Tsopmbeng, D.A. Fontem and K.F. Yamde Evaluation of culture media for growth and sporulation of Phytophthoracolocasiae Racib., causal agent of taro leaf blightInt. J. Biol. Chem. Sci. 6(4): 1566-1573, August 2012

[5] M. Mohsan S. Ali M. Umar Shahbaz Saba Saeed M. Burhan In vitro efficacy of different growth media and crude plant extracts against mycelia growth of PhytophthoracapsiciJournal of Applied Biology \& Biotechnology Vol. 5 (04), pp. 043-047, July-August, 2017

[6] Basu S, Bose C, Ojha N, et al. Evolution of bacterial and fungal growth media. Bioinformation. 2015;11(4):182-184. doi:10.6026/97320630011182

[7] Deivanayaki $M$ and Iruthayaraj AP, Alternative vegetable nutrient source for microbial growth, Inter J Biosci, 2012; 2: 47-51. 9.

[8] Famurewa and O.M. David, 2008. Formulation and Evaluation of Dehydrated Microbiological Media from Avocado Pear (Peasea americana Cmill). Research Journal of Microbiology, 3: 326-330.)

[9] Jamel P., Alam M. Z. and Umi N.,( 2008) Media optimization for bio proteins production from cheaper carbon source,.. J. of Engi. Sci. and Techno., 3(2) 124-130.

[10] Kasanadze AK (2000) Replacement of Agar by cassava flour in microbial media. BSc Dissertation University of Malawi, Bunda College of Agriculture, Lilongwe.

[11] Bromke BJ, Furiga M, Carrageenan is a desirable substitute for agar in media for growingTrichoderma vginali. Microbiol. Methods, 1991; 13: 61-65.

[12] Mondal AK, Sengupta S, Bhowal J, Bhattacharya DK, Utilization Of fruit wastes in producing single cell protein. Inter. J. Sci. Envn. Tech, 2012; 1: 430438.

[13] Kandari V and Gupta S, Bioconversion of vegetable and fruit peel wastes in viable product, J. Microbiol. Biotech. Res., 2012; 2: 308-312.

[14] Arulanantham R, Pathmanathan S, Ravimannan N and Kularajany N, Alternative culture media for bacterial growth using different formulation of protein sources. Nat. Prod. PlantResour., 2012; 2: 697-700.

[15] Ravimannan N, Arulanantham R, Pathmanathan S and Kularajani N, Alternative culturemedia for fungal growth using different formulation of protein sources, Annals of Biol.Res, 2014; 5: 36-39. 